\title{
Crossbreeding Results in Canadian Dairy Cattle for Production, Reproduction and Conformation
}

\author{
Lawrence R. Schaeffer ${ }^{*}$, Edward B Burnside ${ }^{2}$, Paige Glover ${ }^{1}$ and Jalal Fatehi ${ }^{1}$ \\ ${ }^{1}$ Centre for Genetic Improvement of Livestock, University of Guelph, Guelph N1G 2W1, Canada \\ ${ }^{2}$ Genetic Consultants Ltd., 195 Barber Street, Fergus, Canada
}

\begin{abstract}
Progeny of Holstein females mated to sires of different breeds were genetically evaluated along with their purebred Holstein contemporaries born in the same herds using multiple trait animal models. The resulting estimated breeding values (EBV) of cows were averaged within breed of sire and compared relative to progeny of purebred Holstein sires for various economic traits. All progeny were born since 2005, and only animals from herds with crossbreds were included in the genetic evaluation models. Crossbred cows were significantly below Holstein sired cows for 305-d EBV for milk yield, but were above Holsteins for fat and protein yields. There were no significant differences between crossbreds and purebreds for somatic cell scores. Crossbred cows and heifers became pregnant sooner after each calving, had higher non-return rates, fewer services, and shorter gestation lengths than purebred Holsteins. Crossbred heifers and cows had lower stillbirth rates due to having smaller calves, and slightly better calving ease. Objectively measured conformation traits (seven) and milking speed and milking temperament were analyzed by multiple trait models. Differences for conformation favoured Holsteins over crossbreds. There were no significant differences for milking speed or temperament between crossbreds and purebreds.
\end{abstract}

Keywords: Crossbreeding, conformation, production, reproduction, milking speed, temperament, heifers, cows.

\section{INTRODUCTION}

Crossbreeding of Holstein dairy cattle to various breeds has been studied in several countries, including Canada, over many years [1-5], but the practice is limited and not exploited as in other species of livestock. Canadian Holstein dams have been mated to sires of other breeds, producing a small population of crossbred animals. Part of the surge in interest has been due to a designed crossbreeding project, called The Two-Plus Project, involving Norwegian Red (NR) sires mated to Holstein $(\mathbf{H O})$ dams. About 70 collaborating herds were willing to breed their Holstein cows to 9 NR sires and to raise the crossbred heifers through their first lactation, or longer. The Norwegian Red breed was chosen due to its years of selection for improved reproduction and health (mastitis)[6]. The Swedish Red (SR) has also been introduced into Canada for the same reasons. Finally, there has been some use of Brown Swiss (BS) and Jersey (JE) bulls mated to Holstein cows with a small number of other breeds like Ayrshire, Montbeliard, and Normande, plus beef breeds. Within the herds that have applied crossbreeding to Holstein dams, about $3 \%$ of the cows were crossbreds.

The crossbred population in Canada can not be used to estimate heterosis because reciprocal crosses do not exist within the same herds, and there are no purebreds of the other breeds within the same herds, as would be included in a designed crossbreeding project. Thus, there is no possibi-

*Address correspondence to this author at the Department of Animal and Poultry Science, University of Guelph, Guelph, Ontario, Canada, N1G 2W1, Tel: 519-824-4120 ext. 56180; Fax: 519-836-9873;

E-mail: 1rs@uoguelph.ca lity for estimation of heterosis effects. Still, producers want to know if crossbreeding can alleviate reproduction and health issues that appear to be increasing in frequency within their herds, and how much production, if any is lost.

From 1972 to 1983 Agriculture Canada studied 10 crossbred groups in their five research stations across Canada, using foundation Holstein and Ayrshire cattle already present at the research stations [5]. The results from 5,070 Holsteins, Ayrshires, and crossbreds gave heterosis for lifetime milk yield of $16.6 \%$. The annualized net returns of crossbreds were $9 \%$ greater than for purebred Holsteins. A two breed rotational crossbreeding system using Holsteins and Ayrshires was recommended from the study.

Inbreeding levels in the Holstein breed have been rising over the last few years and currently the average inbreeding coefficient is between 6-7\% in Canada. The effects of inbreeding have been reported $[7,8]$. Producers are noticing an increase in reproduction and health problems in their herds, but not so much any decreases in production due to inbreeding [9]. The Canadian Dairy Network [10] estimated inbreeding depression for milk production to be $18.4 \mathrm{~kg}$ per $1 \%$ increase in inbreeding (Canadian Dairy Network website), $1.1 \mathrm{~kg}$ for fat yield and $0.5 \mathrm{~kg}$ for protein yield. With a $6 \%$ inbreeding level the production losses could be $110 \mathrm{~kg}$, $6.6 \mathrm{~kg}$, and $3.2 \mathrm{~kg}$ per lactation for milk, fat, and protein, respectively. Crossbreeding brings inbreeding coefficients down to 0 and if the correct breeds are chosen, reproduction and health issues tend to decrease as well [3].

The objectives of this study were to genetically evaluate purebred and crossbred animals (from purebred Holstein dams) from herds that have crossbreds for production, repro- 
duction, conformation, milking speed, and milking temperament, and to compare estimated breeding values of progeny groups within breeds of sire. The period of study (2005 to 2010) allowed many cows to have three lactations of data.

\section{MATERIAL AND METHODS}

\section{Data Files}

Data files for production, conformation, and reproduction were obtained from Canadian Dairy Network (CDN) databases. The last updated data from $\mathrm{CDN}$ were received in March of 2011 with the latest test day date of January 21, 2011. Test day records, conformation, and fertility data files were provided. Data were collected by CanWest Dairy Herd Improvement and Holstein Canada. All files were searched for animals born to Holstein (HO) dams and sired by any non HO sires. The purebred herdmates of the crossbreds were extracted and included in the analysis. Five breeds of sire with sufficient numbers of progeny to be included in the study were Holstein (HO), Brown Swiss(BS), Jersey(JE), Norwegian Red(NR), and Swedish Red(SR). Progeny of all other breed crosses were removed.

Data were combined with pedigree information from $\mathrm{CDN}$ and breed associations, but non-HO sires were assumed to have unknown parents. Thus, relationships among bulls within a non-HO breed were not included. Crossbred animals could be genetically related to each other and to $\mathrm{HO}$ contemporaries through their $\mathrm{HO}$ dams within and across herds, and due to having the same sire. In total there were 175,348 animals in the pedigree file. HO cows had the majority of the records (about 97\%), followed by NR, JE, $\mathrm{BS}$, and SR, respectively.

Numbers of test day records, cows, and sires by breed and lactation number are given in Tables 1-4. There were 128,376 reproduction records on 55,648 cows, 30,269 type classifications, and 38,163 records on milking speed and temperament.

\section{Production Traits}

Production traits were $24 \mathrm{~h}$ test day milk, fat, and protein yields, and somatic cell scores between 5 and 365 days in milk from the first three lactations. Somatic cell scores (SCS) were calculated from test day somatic cell counts (SCC) as

$$
S C S=\left(\log _{2} \frac{S C C}{100,000}\right)+3
$$

The production traits were analyzed by a multiple trait test day animal model using order 4 Legendre polynomials. Each trait (milk, protein, fat, and SCS) was analyzed separately, but within those, lactations 1, 2, 3 and later were considered as separate traits. The model was

$$
\begin{gathered}
y_{i j m k l h}=(H T D)_{i}+\sum_{j=0}^{n} b_{j l}:(P A S) z_{i j m k l h}+\sum_{m=0}^{n} w_{m l}:(B S) z_{i j m k l h} \\
+\sum_{k=0}^{n} a_{k l} z_{i j m k l h}+\sum_{k=0}^{n} p_{k l} z_{i j m k l h}+e_{i j m k l h},
\end{gathered}
$$

where

$y_{i j m k l h}$ is a test day production record of cow $k$ in lactation $l$, breed of sire group $m$ and parity-age-season group $j$, in herd-test-date $i$.

$(H T D)_{i}$ is the $i^{t h}$ herd-test-date subclass, fixed,

$z_{i j m k h}$ are Legendre polynomials of order $n=4$, as covariates of days in milk,

$b_{j l}:(P A S)$ are $n$ regression coefficients, nested within each level of parity-age-season of calving, fixed curves, for lactation $l$,

$w_{m l}:(B S)$ are $n$ regression coefficients, nested within breed of sire groups (HO, NR, SR, BS, JE), for lactation $l$, fixed curves,

$a_{k l}$ and $p_{k l}$ are order $n$ random regression coefficients nested within each animal and lactation group (first, second, or third and later), and

$e_{i j m k l h}$ are temporary environmental effects within days in milk (dim) groups, of which there were four groups of dim per lactation (5-45, 46-115, 116-265, and 266-365 d).

The covariance matrices of the random effects were

$$
\operatorname{Var}\left(\begin{array}{c}
a \\
p \\
e
\end{array}\right)=\left(\begin{array}{ccc}
A \bigotimes G & 0 & 0 \\
0 & I \bigotimes P & 0 \\
0 & 0 & R
\end{array}\right),
$$

where $A$ is the additive genetic numerator relationship matrix, $G$ is a matrix of order $3(n+1)$ of genetic covariances among the random regression coefficients, $P$ is a matrix of order $3(n+1)$ of permanent environmental covariances among the random regression coefficients, and $R$ is a diagonal matrix with four different possible residual variances per lactation group depending on days in milk for a test day record. All parameter values were obtained from the Canadian Test Day Model evaluation system [11] from Canadian Dairy Network. Mixed model equations were solved by Gauss-Seidel iteration using customized software.

Heterosis effects could not be estimated from the available data. There were no herds in the data which had purebred females of two or more breeds, and no herds with crosses on $\mathrm{HO}$ dams and reciprocal crosses on other purebred females. There were only $\mathrm{HO}$ dams and crosses to HO dams. There have been no NR or SR females imported into Canada. Therefore, the breed of sire group effects in the models contain some of the heterosis effects.

Breed of sire group effects were genetic group effects, so that Estimated Breeding Values (EBV) were calculated as follows:

1. $\quad c_{j l}=w_{j l}+a_{k l}$ for animal $\ell$, which is the sum of the breed of sire regression coefficients plus the animal regression coefficients depending on the breed of sire for that animal and lactation number, then

2. A 305-d EBV for milk, fat, or protein yields, in a lactation for an animal is given by

$$
\begin{aligned}
E B V_{l}=212.84\left(c_{0 l}\right)-61.44\left(c_{1 l}\right)- & 51.78\left(c_{2 l}\right) \\
& -29.76\left(c_{3 l}\right)-1.35\left(c_{4 l}\right)
\end{aligned}
$$


3. The EBV for somatic cell scores was the average daily SCS value between 5 and 305 days in milk.

4. The average EBVs were calculated within each breed of sire and lactation number, and the average values for purebred $\mathrm{HO}$ cows were subtracted from all of the other breed averages.

5. The variances of EBVs within breed of sire were computed, divided by the number of animals, and square roots were taken to obtain standard errors of the estimates.

EBVs of crossbreds would contain some heterosis effects, and this must be kept in mind when reviewing the results of all analyses.

\section{Reproduction Traits}

There were 8 heifer traits (prior to and including first parity), and $8 \mathrm{cow}$ traits for subsequent parities. The reproduction traits for heifers were age at first service (in days), 56 -day non-return rate $(\%)$, number of services, days from first service to conception, gestation length (days), calving ease, stillbirth incidence, and calf size. For older cows, days from calving to first service was used in place of age at first service, and all other traits were the same as for heifers. Calving ease was a 4 category trait (1=unassisted, $2=$ easy pull, 3=hard pull, and 4=surgery), and calf size was a 3 category trait ( $1=$ average, $2=$ large, $3=$ very large) and both were analyzed as continuous traits. Multiple trait models for these traits were described by [12], and include the factors of year-month of birth, year-season-herd, year-month of freshening, breed of sire, sires of calves, age-month-sex of calf effects, animal additive genetic, and animal permanent environmental (for cow traits) effects. The factors in the models varied depending on the trait [12].

Genetic relationships among animals were included. The genetic covariance matrix and the permanent environmental covariance matrix, both of order 16, utilized values from [12] and residual covariance matrices for heifers or cows, respectively, of order 8 . Customized software was written for the analyses.

Estimated breed of sire effects were added to animal genetic solutions to give EBV. Average EBVs were calculated within the 5 breed of sire groups, and variances and standard errors of EBVs were calculated within each breed of sire group. HO sire group average EBVs were subtracted from the EBV averages of other breed of sire groups.

\section{Conformation Traits}

Conformation traits are collected by classifiers of Holstein Canada. Conformation traits included 7 traits that were measured, and not subjectively scored, to avoid classifier biases against crossbred animals. The traits were pin width (PW), rump angle (RA), rear udder height (RAH), rear udder width(RAW), stature (ST), teat length (TL), and udder depth(UD). Measured traits were reported in centimetres. Conformation is only scored on first lactation animals, and thus, there is only one record per individual for each trait.

The same model was applied to all traits in a multiple trait system. The model for each trait was

$$
\begin{aligned}
& \quad y_{i j k l m h}=A_{i}+S_{j}+B_{k}+(R C)_{l}+(H R C)_{l m}+a_{h}+e_{i j k l m h}, \\
& \text { where }
\end{aligned}
$$

$y_{i j k l m h}$ is the conformation measurement for a trait, $A_{i}$ is an age at calving effect (in monthly categories), fixed, $S_{j}$ is a stage of lactation effect (in monthly categories), fixed,

$B_{k}$ is a breed of sire group effect, fixed,

$(R C)_{l}$ is a round-classifier subclass, fixed,

$(H R C)_{l m}$ is a herd-round-classifier subclass, random,

$a_{h}$ is an animal additive genetic effect, random, and

$e_{i j k l m h}$ is a residual error, random.

Let $a, h$, and $e$ be vectors for animal additive genetic, herd-round-classifier, and residual effects, then the assumed covariance structure was

$$
\operatorname{Var}\left(\begin{array}{l}
a \\
h \\
e
\end{array}\right)=\left(\begin{array}{ccc}
A \bigotimes G & 0 & 0 \\
0 & I \bigotimes H & 0 \\
0 & 0 & R
\end{array}\right),
$$

where $A$ is the additive numerator relationship matrix, $G$ is the genetic covariance matrix of order $7, H$ is the (HRC) covariance matrix and $R$ is the residual covariance matrix of order 7 .

Heritabilities for the traits were obtained from studies at Canadian Dairy Network (CDN), but CDN does not use a multiple trait model for conformation traits nor does it have random (HRC) effects in its model. Therefore, the phenotypic covariance matrix among the 7 traits was obtained from the data. Genetic variances were derived by multiplying the phenotypic variances times the heritability values. Genetic correlations were assumed to be equal to the phenotypic correlations, and thus, genetic covariances were derived. The residual covariance matrix was equal to the phenotypic covariance matrix minus the genetic covariance matrix. The matrix $H$ was assumed to be equal to $R$. Lastly, the genetic and residual covariance matrices were verified to be positive definite before analyzing the data. Customized software was written for these analyses.

Estimated breed of sire effects were added to animal genetic solutions to give EBV. Average EBVs were calculated within the 5 breed of sire groups, and variances and standard errors of EBVs were calculated within each breed of sire group. HO sire group averages were subtracted from the average EBVs of other breed of sire groups.

\section{Milking Speed and Temperament}

Subjective appraisals of milking speed and temperament during the first six months of first lactation were provided by herd owners to milk supervisors. Milking speed was a 5 category trait $(1=$ very slow, $2=$ slow, 3=average, $4=$ fast, $5=$ very fast), and milking temperament was a 5 category trait ( $1=$ very nervous, $2=$ nervous, $3=$ average, $4=$ calm, $5=$ very calm). A multiple trait (two trait) animal model was identical to the models used for the conformation traits. Covariance matrices were derived in the same manner as for conformation traits. The same software as for the conformation traits was used. 


\section{RESULTS}

\section{Differences among Dams}

The question arises about the qualities of the $\mathrm{HO}$ dams that were mated to sires of other breeds, compared to $\mathrm{HO}$ dams of purebreds. For each group of traits the average EBVs of the dams for each breed of sire group were calculated and compared against the Holstein breed. There were no statistically significant differences for any group of traits or any breed of sire $(p=0.88$ for production traits, $p=0.95$ for milking behaviour, $p=0.75$ for conformation traits, and $p=0.90$ for reproduction traits). The only exception was stature which was generally shorter (by less than 1 $\mathrm{cm}$ ) for $\mathrm{HO}$ dams of crossbreds than for $\mathrm{HO}$ dams of purebreds $(p=0.04)$. Thus, the dams were genetically similar for all crossbred groups meaning that crosses occurred randomly with respect to $\mathrm{HO}$ dams. Hence none of the results were biased by differential mating of non-HO sires to HO dams.

\section{Production Traits}

All of the crossbreds gave significantly less milk yield than Holsteins, as expected, ranging from $-240 \mathrm{~kg}$ to $-880 \mathrm{~kg}$ in first lactation to $-145 \mathrm{~kg}$ to $-654 \mathrm{~kg}$ in third lactations (although numbers of animals and records in third lactation were low) (Table 1). Fat and protein yields were significantly higher for crossbreds than for Holsteins, except for protein yields in Jersey sired crossbreds, and fat and protein yields in NR and SR crossbreds in second lactations. Jersey crosses excelled in fat yield (Tables $\mathbf{2}$ and $\mathbf{3}$ ).

Table 1. 305-d Milk Production, kg Compared to Holstein Sire Breed Average

\begin{tabular}{|c|c|c|c|c|}
\hline Breed & item & 1st Lact & 2nd Lact & 3rd Lact \\
\hline \multirow[t]{5}{*}{$\mathrm{BS}$} & cows & 189 & 76 & 30 \\
\hline & sires & 48 & 28 & 14 \\
\hline & TD records & 1358 & 520 & 134 \\
\hline & Est. Diff. & -358 & -442 & -184 \\
\hline & $\mathrm{SE}$ & 38 & 46 & 44 \\
\hline \multirow[t]{5}{*}{$\mathrm{JE}$} & cows & 314 & 96 & 19 \\
\hline & sires & 72 & 30 & 12 \\
\hline & TD records & 1968 & 495 & 75 \\
\hline & Est. Diff. & -880 & -996 & -264 \\
\hline & $\mathrm{SE}$ & 24 & 27 & 26 \\
\hline \multirow[t]{5}{*}{ NR } & cows & 589 & 300 & 89 \\
\hline & sires & 9 & 7 & 6 \\
\hline & TD records & 4208 & 1838 & 345 \\
\hline & Est. Diff. & -240 & -885 & -145 \\
\hline & $\mathrm{SE}$ & 20 & 24 & 23 \\
\hline \multirow[t]{5}{*}{ SR } & cows & 76 & 28 & 10 \\
\hline & sires & 3 & 2 & 2 \\
\hline & TD records & 519 & 184 & 39 \\
\hline & Est. Diff. & -353 & -893 & -654 \\
\hline & $\mathrm{SE}$ & 47 & 49 & 52 \\
\hline \multirow[t]{3}{*}{$\mathrm{HO}$} & cows & 25,026 & 10,014 & 2781 \\
\hline & sires & 2205 & 1341 & 623 \\
\hline & TD records & 177,518 & 64,184 & 12,389 \\
\hline
\end{tabular}

Table 2. 305-d Fat Production, kg Compared to Holstein Sire Breed Average

\begin{tabular}{|c|c|c|c|c|}
\hline Breed & item & 1st Lact & 2nd Lact & 3rd Lact \\
\hline \multirow[t]{5}{*}{ BS } & cows & 188 & 76 & 28 \\
\hline & sires & 47 & 28 & 13 \\
\hline & TD records & 1335 & 487 & 131 \\
\hline & Est. Diff. & 4.6 & 8.4 & 25.4 \\
\hline & SE & 1.3 & 1.8 & 1.7 \\
\hline \multirow[t]{5}{*}{$\mathrm{JE}$} & cows & 314 & 96 & 19 \\
\hline & sires & 72 & 30 & 12 \\
\hline & TD records & 1911 & 484 & 75 \\
\hline & Est. Diff. & 16.5 & 19.8 & 36.1 \\
\hline & SE & 0.9 & 1.1 & 1.1 \\
\hline \multirow[t]{5}{*}{ NR } & cows & 589 & 295 & 88 \\
\hline & sires & 9 & 7 & 6 \\
\hline & TD records & 4049 & 1725 & 319 \\
\hline & Est. Diff. & 6.0 & -15.2 & 5.1 \\
\hline & $\mathrm{SE}$ & 0.7 & 0.9 & 0.9 \\
\hline \multirow[t]{5}{*}{ SR } & cows & 76 & 28 & 10 \\
\hline & sires & 3 & 2 & 2 \\
\hline & TD records & 509 & 177 & 34 \\
\hline & Est. Diff. & 9.2 & -4.6 & 24.7 \\
\hline & SE & 1.4 & 1.7 & 1.7 \\
\hline \multirow[t]{3}{*}{$\mathrm{HO}$} & cows & 24,923 & 9962 & 2755 \\
\hline & sires & 2200 & 1330 & 621 \\
\hline & TD records & 169,326 & 61,159 & 11,674 \\
\hline
\end{tabular}

Table 3. 305-d Protein Production, kg Compared to Holstein Sire Breed Average

\begin{tabular}{|c|c|c|c|c|}
\hline Breed & item & 1st Lact & 2nd Lact & 3rd Lact \\
\hline \multirow[t]{5}{*}{ BS } & cows & 188 & 76 & 28 \\
\hline & sires & 47 & 28 & 13 \\
\hline & TD records & 1335 & 487 & 131 \\
\hline & Est. Diff. & 2.4 & 3.6 & 9.4 \\
\hline & SE & 1.0 & 1.2 & 1.1 \\
\hline \multirow[t]{5}{*}{$\mathrm{JE}$} & cows & 314 & 96 & 19 \\
\hline & sires & 72 & 30 & 12 \\
\hline & TD records & 1911 & 484 & 75 \\
\hline & Est. Diff. & -8.2 & -5.8 & 27.9 \\
\hline & SE & 0.6 & 0.7 & 0.7 \\
\hline \multirow[t]{5}{*}{ NR } & cows & 589 & 295 & 88 \\
\hline & sires & 9 & 7 & 6 \\
\hline & TD records & 4049 & 1725 & 319 \\
\hline & Est. Diff. & 1.6 & -13.8 & 1.6 \\
\hline & SE & 0.5 & 0.6 & 0.6 \\
\hline \multirow[t]{5}{*}{ SR } & cows & 76 & 28 & 0 \\
\hline & sires & 3 & 2 & 0 \\
\hline & TD records & 509 & 177 & 0 \\
\hline & Est. Diff. & 4.5 & -10.3 & 12.5 \\
\hline & SE & 1.3 & 1.4 & 1.4 \\
\hline \multirow[t]{3}{*}{$\mathrm{HO}$} & cows & 24,923 & 9962 & 2566 \\
\hline & sires & 2200 & 1330 & 585 \\
\hline & TD records & 169,326 & 61,159 & 10,852 \\
\hline
\end{tabular}


Table 4. Lactation Daily Somatic Cell Scores Compared to Holstein Sire Breed Average

\begin{tabular}{|c|c|c|c|c|}
\hline Breed & item & 1st Lact & 2nd Lact & 3rd Lact \\
\hline \multirow[t]{5}{*}{ BS } & cows & 188 & 75 & 28 \\
\hline & sires & 47 & 27 & 13 \\
\hline & TD records & 1323 & 481 & 131 \\
\hline & Est. Diff. & -0.14 & 0.04 & -0.67 \\
\hline & SE & 0.02 & 0.02 & 0.02 \\
\hline \multirow[t]{5}{*}{$\mathrm{JE}$} & cows & 313 & 96 & 19 \\
\hline & sires & 71 & 30 & 12 \\
\hline & TD records & 1895 & 482 & 72 \\
\hline & Est. Diff. & 0.36 & 0.25 & -0.28 \\
\hline & SE & 0.01 & 0.01 & 0.01 \\
\hline \multirow[t]{5}{*}{ NR } & cows & 579 & 288 & 87 \\
\hline & sires & 9 & 7 & 6 \\
\hline & TD records & 3956 & 1680 & 318 \\
\hline & Est. Diff. & 0.06 & -0.02 & 0.04 \\
\hline & SE & 0.01 & 0.01 & 0.01 \\
\hline \multirow[t]{5}{*}{ SR } & cows & 76 & 28 & 0 \\
\hline & sires & 3 & 2 & 0 \\
\hline & TD records & 505 & 177 & 0 \\
\hline & Est. Diff. & 0.42 & -0.28 & -0.17 \\
\hline & SE & 0.04 & 0.02 & 0.02 \\
\hline \multirow[t]{3}{*}{$\mathrm{HO}$} & cows & 24,505 & 9794 & 2513 \\
\hline & sires & 2189 & 1321 & 577 \\
\hline & TD records & 165,915 & 59,889 & 10,598 \\
\hline
\end{tabular}

Somatic cell scores were greater for JE and SR crossbreds in first lactations, while NR showed very small differences from HO. BS gave lower SCS in first and third lactations compared to $\mathrm{HO}$ (Table 4).

\section{Reproductive Traits}

Age at first service in heifers (Fig. 1) has a reasonable heritability for a reproductive trait. Brown Swiss sired crossbreds were not different from Holstein purebreds for this trait, but JE and NR were slightly older than Holsteins, while SR crossbreds were a day younger at first service. Gestation lengths (Fig. 1) of JE, NR, and SR crossbreds, however, were 1 to 3 days shorter than for $\mathrm{HO}$, but the BS crosses were 2.5 days longer as heifers in their first parity.

Calving to first service intervals (Fig. 1) were shorter for crossbreds, except for BS which was a half day longer than HO purebreds. Thus, crossbreds started to be re-bred sooner after calving than $\mathrm{HO}$ purebreds by 2.5 to 4.25 days. In addition, BS, JE, and NR crossbreds had higher non-return rates than $\mathrm{HO}$ as heifers, and all crosses were higher than HO as cows by 2.9 to $9.4 \%$ (Fig. 2). Looking at number of services (Fig. 2), crossbreds had significantly lower number of services, but these differences were very small. The differences were bigger for lactating cows than heifers. Another measure of fertility is the interval from first service to conception (Fig. 2). Crossbreds had significantly shorter intervals as heifers and cows (from -4 to -11 days) than $\mathrm{HO}$ purebreds which agrees with the higher non-return rates.

Once pregnancy is achieved, the percentage of stillbirths (Fig. 3) becomes important. Crossbreds had a significantly

\section{Intervals, days}
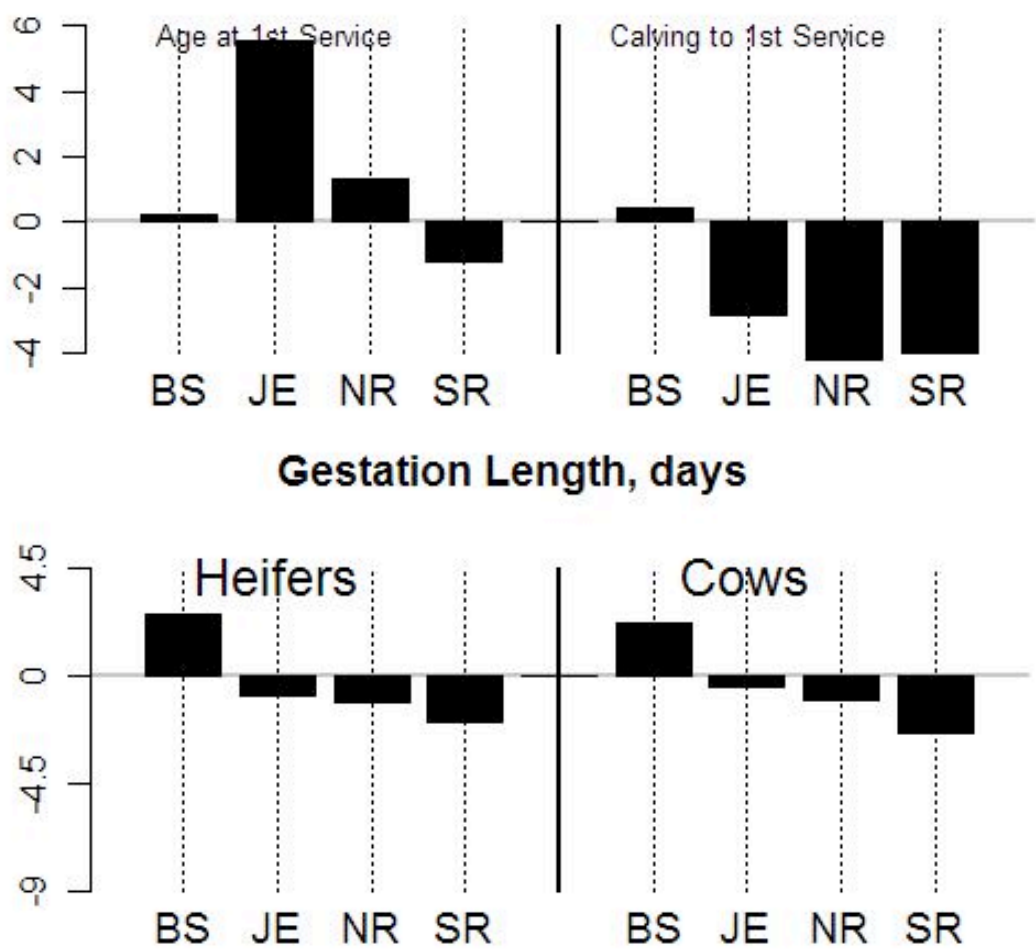

Fig. (1). Contrasts of crossbreds to Holstein sired purebreds for age at first service, interval from calving to first service and gestation lengths, all in days, where BS is Brown Swiss, JE is Jersey, NR is Norwegian Red, and SR is Swedish Red sired crossbreds. 
1st Service to Conception, days

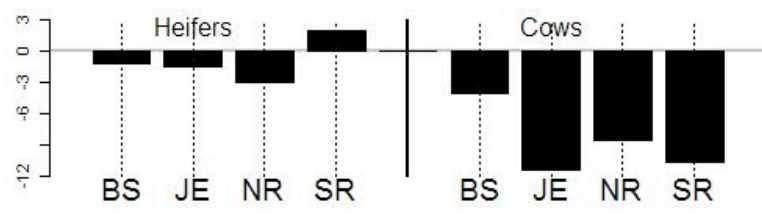

Non Return Rate, \%

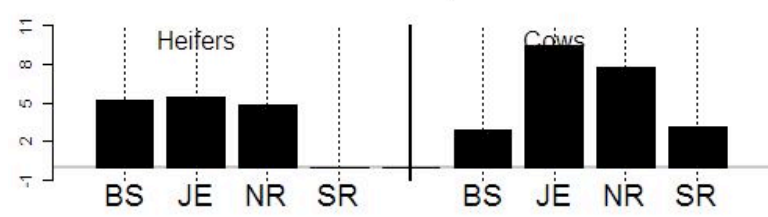

Number of Services

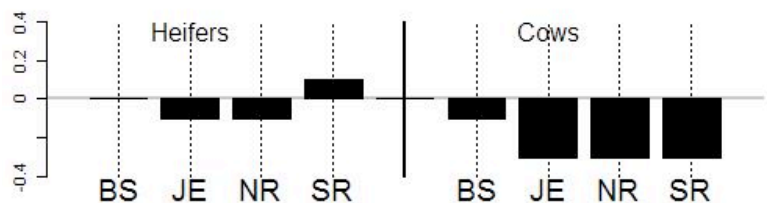

Fig. (2). Contrasts of crossbreds to Holstein sired purebreds for days from 1st service to conception, non-return rates, and number of services, where BS is Brown Swiss, JE is Jersey, NR is Norwegian Red, and SR is Swedish Red sired crossbreds.

Calf Size

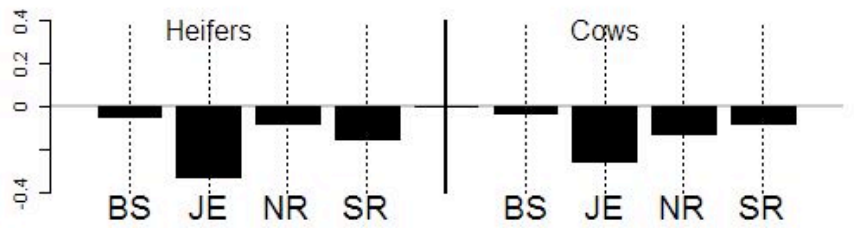

Calving Ease

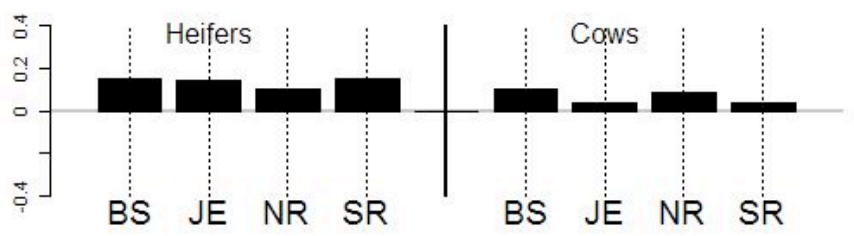

Stilbirths, \%

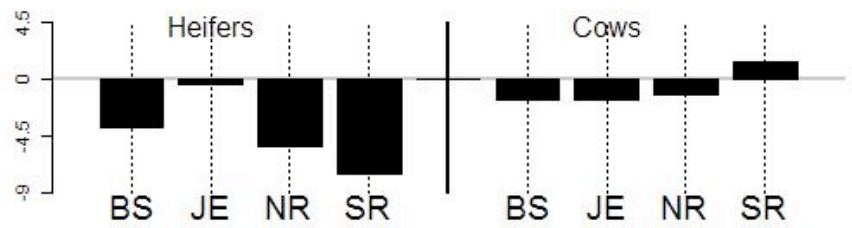

Fig. (3). Contrasts of crossbreds to Holstein sired purebreds for calving ease (4 categories), calf size (3 categories), and stillbirths (percentage), where BS is Brown Swiss, JE is Jersey, NR is Norwegian Red, and SR is Swedish Red sired crossbreds.

lower percentage of stillbirths than $\mathrm{HO}$ by 1 to $7 \%$ as heifers and $1.5 \%$ lower as cows, because stillbirths are generally lower in older animals. The lower stillbirth rates are partially attributed to smaller calf size (Fig. 3). Crossbreds had significantly smaller calves, but practically the differences were small. Calving ease was significantly better for crossbreds. 


\section{Milking Behaviour}

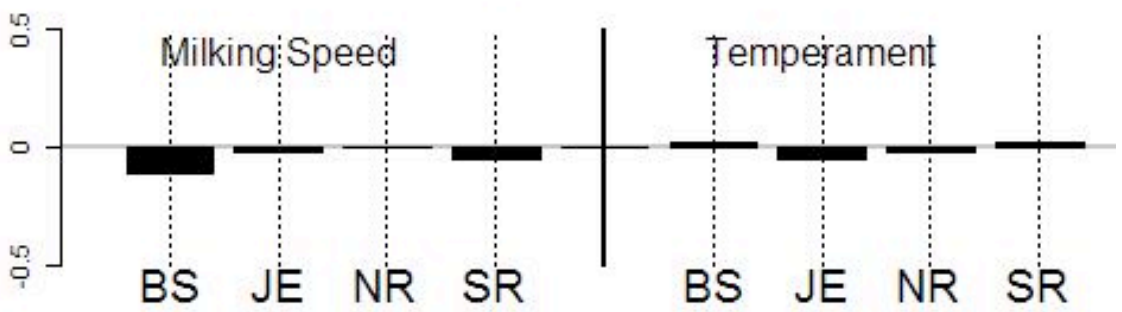

Fig. (4). Contrasts of crossbreds to Holstein sired purebreds for milking speed and milking temperament, five category traits, where BS is Brown Swiss, JE is Jersey, NR is Norwegian Red, and SR is Swedish Red sired crossbreds.

\section{Milking Behaviour}

Canadian dairy farmers who are on milk recording, score their heifers on milking speed and temperament early in their first lactation. These data (Fig. 4) show that there were no significant differences between crossbreds and purebreds for either milking speed or milking temperament, except slightly slower milkers for BS crosses and less desirable temperament ratings for JE crosses.

\section{Conformation Traits}

HO were significantly taller in stature than all crosses, and as expected the smaller stature of the crossbreds contributed to deeper udders, as measured from the floor of the udder to the point of the hock, and lower rear udder attachments (Fig. 5). Additionally, crossbreds had narrower pins,

Stature, $\mathrm{cm}$

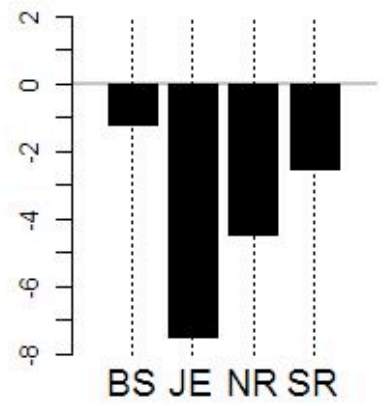

BS JE NR SR and narrower rear udder attachments with BS and JE crosses being closer to $\mathrm{HO}$ than the Scandinavian crosses in rear udder attachment width (Fig. 6). JE crosses were flatter in their rumps with higher pins than other crosses and HO. Teat length and placement is of concern with robotic milkers, and the JE and BS crosses were slightly longer in teats than HO, while the two Scandinavian crosses had shorter teats.

\section{DISCUSSION}

\section{Production}

Production traits are the major source of income from a dairy cow. The Holstein is the world leader in milk production, and crossing $\mathrm{HO}$ dams to other breeds of sire is not expected to surpass the HO. NR and SR breeds had only 9

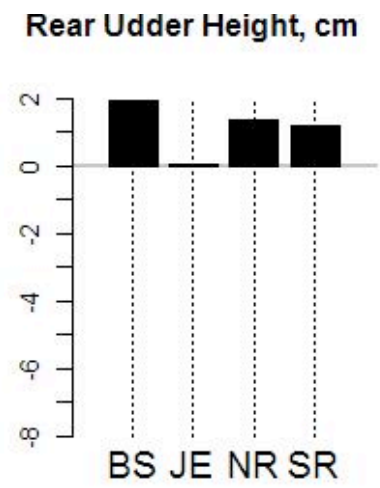

Udder Depth, $\mathrm{cm}$

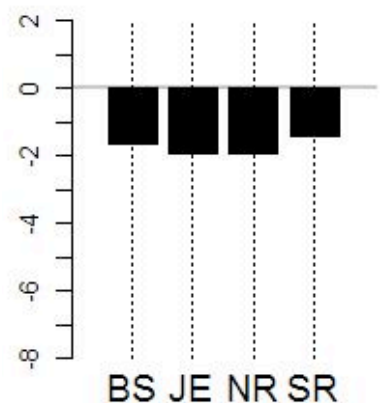

Fig. (5). Contrasts of crossbreds to Holstein sired purebreds for stature, rear udder height, and udder depth, all in centimeters, where BS is Brown Swiss, JE is Jersey, NR is Norwegian Red, and SR is Swedish Red sired crossbreds. 
Pin Width, $\mathrm{cm}$

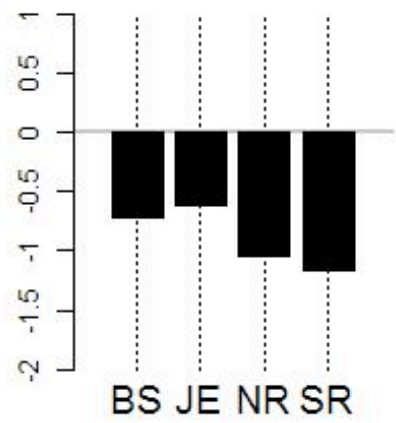

Rear Udder Width, cm

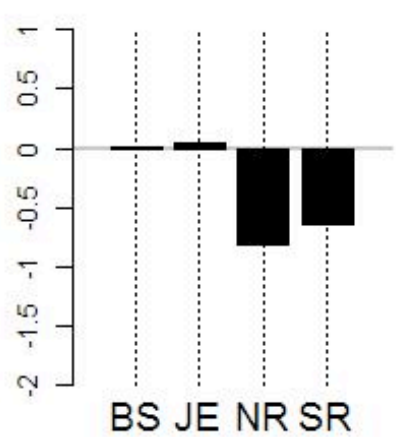

Rump Angle, $\mathrm{cm}$

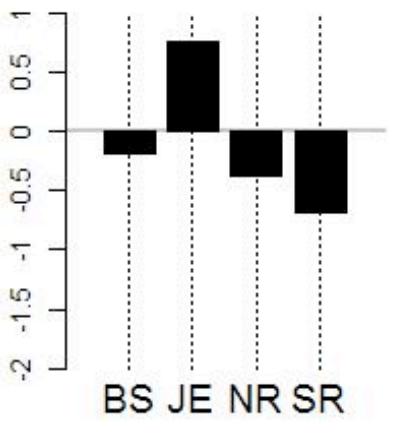

Teat Length, $\mathrm{cm}$

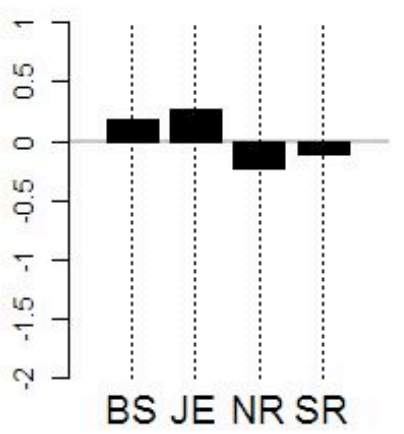

Fig. (6). Contrasts of crossbreds to Holstein sired purebreds for pin width, rump angle, rear udder width and teat length, all in centimeters, where BS is Brown Swiss, JE is Jersey, NR is Norwegian Red, and SR is Swedish Red sired crossbreds.

and 3 sires, respectively, represented in Canada. Those particular sires were selected specifically to be of value to Canadian producers and, therefore, do not represent a random sample of sires from those breeds. JE and BS sires were more numerous and represented a sample of available sires in those two breeds. The JE or BS sires were chosen by producers, and could be considered more randomly selected than NR or SR sires.

Practically speaking, HO were superior for milk, but not for total milk solids production. In most milk markets except those paying very little fat or protein differentials, the value of total production for purebreds and crossbreds would be similar because water content is not rewarded. Typical prices from Dairy Farmers of Ontario, which vary weekly, might be $0.04 / \mathrm{kg}$ milk, $9.92 / \mathrm{kg}$ fat, and $7.16 / \mathrm{kg}$ protein, then the crossbreds would have increased values of $\$ 48.50, \$ 69.77$, $\$ 61.38$, and \$109.36 for BS, JE, NR, and SR, respectively, over purebred $\mathrm{HO}$ for first lactation production. Market prices may differ across Canada and in other countries over time. There were no practical differences in somatic cell scores between crossbreds and purebreds, although JE crosses were definitely higher than other breeds of sire for this indicator of mastitis.

By comparison, a $1 \%$ increase in inbreeding could result in decreases of $18.4 \mathrm{~kg}$ milk, $1.1 \mathrm{~kg}$ fat, and $0.5 \mathrm{~kg}$ protein in purebred $\mathrm{HO}$ matings. Thus, an animal that is $6 \%$ inbred could have its production lowered by as much as $110 \mathrm{~kg}$ milk, $6.6 \mathrm{~kg}$ fat, and $3.2 \mathrm{~kg}$ protein. Using the same market prices as in the previous paragraph, these numbers represent a loss of $\$ 92.78$. Avoiding inbreeding can avoid these losses, and using crossbreeding could increase production value by similar amounts, depending on the breeds.

Because production traits have high heritabilities, the amount of heterosis is generally lower than for traits with low heritabilities. Studies have ranged from 6 to $7 \%$ heterosis for milk yields [13]. Thus, the above results for crossbreds should be adjusted downwards, perhaps. Economic heterosis has been estimated at 2-3\% [14], and at $16 \%$ for lifetime milk yield [5]. The amount of heterosis in this study is indeterminant.

\section{Reproduction}

Reproduction consists of the ability to become pregnant (number of services and non-return rates) and the ability to produce a calf (calving ease and stillbirth rates). Age at first service refers to the start of an animal's reproductive life. BS, JE, and NR were first bred 1 to 3 days later than HO, but SR was a day earlier than $\mathrm{HO}$, and likely indicate differences in maturity rates of females. On the other side of the coin, gestation lengths were a little shorter for crossbreds, except for BS. Thus, age at first calving were similar among the 
breeds. Shorter than average gestations usually lead to easier calvings because of slightly smaller calves.

Differences in number of services and non-return rates heavily favour crossbreds over HO. Crossbreds would have lower second and later insemination costs than HO. Subsequently, the crossbreds would begin their next lactations sooner, if they had the same number of days dry. The crossbred cow seems to be more robust in reproductive ability. With shorter intervals between calvings, crossbreds should have greater lifetime production.

Crossbred females had significantly easier calvings than $\mathrm{HO}$ females as heifers and as cows, most likely due to smaller calves and shorter gestation lengths. In Scandinavia, there has been selection for calving ease and stillbirth rates for many decades compared to North America. Stillbirth rates were much lower for crossbred females than for HO. An important consequence is that plenty of replacement calves are produced in a well-managed crossbred herd, leaving greater scope for culling when replacements calve out, and expanded sales opportunity for crossbred replacements. Most producers resort to crossbreeding to improve reproduction, and the above evidence shows that it works.

Heterosis should be much higher for these lowly heritable traits, and producers should be seeking matings that give as much heterosis as possible with every mating, if reproductive issues exist in the herd.

\section{Conformation and Milking Behaviour}

Often crossbreds are cited for milking slowly or having a bad temperament. Neither of these traits have a huge economic impact on efficiency, but dealing with slow milkers or cows that are difficult to handle is not pleasant and some producers may be opposed to crossing for this reason. However, the results of this study do not support those beliefs. There were no significant differences between crossbreds and purebreds in these data, based on scores given by producers. As with any breed there will be individuals with certain behaviour problems, but these results show that every breed and crossbreeds have similar likelihoods of those traits to appear.

The HO cow is considered beautiful by the majority of producers in Canada. Beauty includes the colour of the hide, the marking patterns, and other production and reproduction functionally related traits. Crossbred animals can and do come in a variety of colour combinations not always considered desirable to everyone, and definitely uncharacteristic of HO purebreds. The crossbreds frequently result in dark legs and black hooves, for example.

The important conformation aspects should be those that lead to longer herd life. Within purebreds, deeper, lower udders with narrower rear attachments have been found to contribute towards higher culling. All crossbreds had deeper udders than HO herdmates, and the BS, NR, and SR crosses had lower rear udder attachment heights, while NR and SR crosses had narrower rear udder attachment widths. In purebred studies, rear udder attachment height has been negatively correlated with survival through first lactation and productive herd life [15], and a strongly attached and shallow udder has been favourably associated with reduced mastitis incidence [16].

\section{CONCLUSION}

Crossbreds in Canada produce less milk, but more fat and protein than purebred Holsteins. Crossbreds reproduce more efficiently than Holsteins due to smaller calf size, with fewer calving problems and fewer stillbirths. These advantages in crossbreds will result in larger numbers of replacement heifers annually. Crossbreds are not a problem for milking either in speed or temperament. They are small to medium in stature, a possible advantage, but deeper udders and narrower, lower rear udder attachments in some crosses compared to Holsteins. The effects of crossbreeding on health traits or survival statistics need to be studied. There is evidence that NR crossbreds have greater immune responses when challenged, and this could lead to fewer health problems [17].

First generation crossbreds have zero inbreeding coefficients and will benefit from heterosis, particularly for reproduction and health traits. Thus, problems in purebreds due to inbreeding can be avoided or, at least reduced by crossbreeding. There are enough different pure breeds in Canada, such that crossbred animals always could be mated to a different breed of sire than either of its parents. This would maintain $100 \%$ heterosis. If breeds and sires are chosen carefully, the best characteristics of each breed could be incorporated into the crossbred individuals. Because there are a limited number of breeds available in Canada, a rotational system that uses HO every 3-4 generations will keep production levels high and maintain a high level of heterosis. Crossbred animals can also be inbred if the parents of an individual are related so that matings should still be monitored closely.

\section{ACKNOWLEDGEMENTS}

This study was instigated by the TwoPlus Crossbreeding Project of Canadian AI organizations started in 2005 through the efforts of Dr. Ted Burnside and Mr. Brian O'Connor of EastGen. Paige Glover did the analyses of early data arising from this project, with help from Jalal Fatehi and Dr. Larry Schaeffer of the Centre for Genetic Improvement of Livestock, Department of Animal Science, OAC, Guelph. Shannon Cartwright and Dr. Bonnie Mallard of the Pathobiology Department in the OVC, Guelph studied immune responses of crossbred calves and heifers. The project was funded by the CanAdvance Program of Agriculture and Agrifood Canada (AAFC), by the Semex Alliance, Guelph, Canada and by Geno Global, Hamar, Norway, and Gencor, Eastern Breeders, and Westgen all members of the Semex Alliance. Thanks are extended to the Canadian Dairy Network for supplying the data collected through Canwest DHI and Holstein Canada. Finally, we particularly extend thanks to the dairy producers that used crossbreeding to generate data for this study.

\section{CONFLICT OF INTEREST}

None declared. 


\section{REFERENCES}

[1] Buckley F, Begley N, Prendville R, Byrne N, Condon T, Curtin B. Crossbreeding the dairy herd - promising results from Moorepark. T Research 2008; 3: 23-5.

[2] Glover PK, Fatehi J, Burnside EB, Schaeffer LR. Breed of sire effect on fertility of first generation crossbred heifers. $9^{\text {th }}$ World Congress Applied to Livestock Production; 2010 August 2-6; Germany,Leipzig.

[3] Heins BJ, Hansen LB, Seykora AJ. Production of pure Holsteins versus crossbreds of Holstein with Normande, Montbeliarde, and Scandinavian Red. J Dairy Sci 2006; 89: 2799-804.

[4] Heins BJ, Hansen LB, Seykora AJ, et al. Crossbreds of Jersey x Holstein compared with pure Holsteins for production, fertility, and body and udder measurements during first lactation. J Dairy Sci 2008; 91: 1270-8.

[5] McAllister AJ, Lee AJ, Batra TR, et al. The influence of additive and non-additive gene action on lifetime yields and profitability of dairy cattle. J Dairy Sci 1994; 77: 2400-14.

[6] Andersen-Ranberg IM, Heringstad B, Klemetsdal G, Svendsen M, Steine T. Heifer fertility in Norwegian dairy cattle: variance components and genetic change. J Dairy Sci 2003; 86: 2706-14.

[7] Kearney JF, Wall E, Villanueva B, Coffey PM. Inbreeding trends and application of optimized selection in the UK Holstein population. J Dairy Sci 2004; 87: 3503-9.

[8] Smith LA, Cassell BG, Pearson RE. The effects of inbreeding on the lifetime performance of dairy cattle. J Dairy Sci 1998; 81: 2729-37.
[9] Muir BL. Genetic gains achieved. Holstein J, August 2011; 74: 22.

[10] Van Doormaal B. Quantifying Inbreeding Depression. [cited: 2008 March]. Available from: http://www.cdn.ca/document.php?id=145

[11] Schaeffer LR, Jamrozik J, Kistemaker GJ, Van Doormaal BJ. Experience with a test-day model. J Dairy Sci 2000; 83: 1135-44.

[12] Jamrozik J, Fatehi J, Kistemaker GJ, Schaeffer LR. Estimates of genetic parameters for Canadian Holstein female reproduction traits. J Dairy Sci 2005; 88: 2199-208.

[13] Ahlborn-Breier G, Hohenboken WD. Additive and non-additive effects on milk production in dairy cattle: Evidence for major individual heterosis. J Dairy Sci 1991; 74: 592-602.

[14] Lopez-Villalobos N, Garrick DJ. Economic heterosis and breed complimentarity for dairy cattle in New Zealand. $7^{\text {th }}$ World Congress Applied to Livestock Production; 2002 Aug 19-23; France, Montpellier.

[15] Rogers GW, Hargrove GL, Cooper JB, Barton EP. Relationships among survival and linear type traits in Jerseys. J Dairy Sci 1991; 74: 286-91

[16] Rogers GW, Hargrove GL, Lawlor TJJ, Ebersole JL. Correlations among linear type traits and somatic cell counts. J Dairy Sci 1991; 74: 1087-91.

[17] Cartwright SL, Begley N, Schaeffer LR, Burnside EB, Mallard BA. Antibody and cell-mediated immune responses and survival between Holstein and Norwegian Red $\times$ Holstein Canadian calves. J Dairy Sci 2010; 94: 1576-85.

\section{Received: September 02, 2011 \\ (C) Schaeffer et al.; Licensee Bentham Open.}

This is an open access article licensed under the terms of the Creative Commons Attribution Non-Commercial License (http://creativecommons.org/licenses/by$\mathrm{nc} / 3.0 /$ ), which permits unrestricted, non-commercial use, distribution and reproduction in any medium, provided the work is properly cited. 